\title{
Revenue Management Perspectives in Small-Farm Winery Operations
}

\author{
Marie G. Kulesza \\ Central Connecticut State University
}

\begin{abstract}
This exploratory multiple case study illustrates how revenue management decisions of small-farm winery owners may contribute to business sustainability in a regulated industry through the lens of dynamic capabilities. Given small-farm winery owners focus on brand development and customer base growth to sustain long-term survival, the findings of this study highlight the connection of revenue management tenets to pricing and inventory decisions to sustain full capacity and maximize revenue. Furthermore, the results indicate that small-farm winery owners' revenue management strategic decisions may be influenced by resource and regulatory constraints and competitors' impact on pricing and distribution tactics.
\end{abstract}

Keywords: dynamic capabilities, revenue management, qualitative, small-farm winery

\section{INTRODUCTION}

Wine is a luxury product; thus, customers' preferences, the number of competitors, and regional accessibility could influence consumers' willingness to pay. The practical application of revenue management by small-farm winery owners can be a successful strategy to promote long-term survival within the construct of revenue management facets. Given small-farm winery owners focus on brand development and customer base growth to sustain long-term survival (Back, Bufquin, \& Park, 2018), revenue management offers the connection of pricing and inventory decisions to sustain full capacity and maximize revenue.

Small-farm wineries are an emerging segment of the winery population in the United States. Of the total number of U.S. wineries, $92.5 \%$ represent small wineries with production levels of less than 50,000 cases of wine annually (USDA, NASS, 2019). Although large, well-established wineries in California dominate the U.S. wine industry, small-farm wineries are steadily emerging with at least one winery in every state. Researchers discovered that over the last two decades there has been over a triple-digit percentage growth in small-farm wineries in some U.S. states including Washington, Oregon, and New York (Lee \& Gartner, 2015; Lim, 2017; Tuck, Gartner, \& Appiah, 2016).

Owners of small-farm winery enterprises operate in a multifaceted business environment and must abide by a unique system of federal and state laws related to the sale and distribution of wine products. Furthermore, these small-farm winery owners grapple with business constraints from increased competition, high operational costs, and limited resource issues that affect how owners produce, market, and sell wine product to be profitable and sustain long-term survival. Many small-farm wineries are located in rural communities and are under pressure to adopt strategies to mitigate the negative impacts of business constraints and improve economic performance to enhance long-term survival. 
Successful small-farm winery owners proactively adapt capabilities and reallocate limited resources to temper the potential negative effects of increased competition and state-level regulatory changes (Newton, Gilinsky, \& Jordan, 2015; Tuck et al., 2016). In particular, alternative revenue management approaches are critical management strategies in the wine sector to generate revenue and create brand awareness. Revenue management is a sophisticated approach by which managers employ effective capacity, pricing and inventory controls, various distribution channels, and other tactics to optimize revenue (Westermann, 2015; Zatta \& Kolisch, 2014). While diversification of revenue management approaches could enhance the operations of small-farm wineries, potential risks and barriers exist for owners.

Prior literature indicates that the practical application of revenue management techniques is a core strategy in airlines, hospitality, and some service industries to maximize profits (Cetin, Demirciftci, \& Bilgihan, 2016; Vinod, 2015). However, researchers have conducted far fewer studies examining the application of revenue management in nontraditional industries such as the wine industry, indicating a gap in the literature. This explorative multiple case study explores small-farm winery owners' decisions to utilize alternative revenue management in the Connecticut wine industry to analyze the affect the practical application of revenue management approaches that contribute to business sustainability. The first section of the paper is a review of the relevant literature on the concept of revenue management strategy and application in the wine sector, the dynamic capabilities framework, and a brief overview of small-farm winery operations in Connecticut. Then is the outline of the multiple-case methodology and description of study procedures, followed by the discussion of the study findings. Finally, the paper concludes with some business implications, limitations, and suggested future research opportunities.

\section{CONCEPT OF REVENUE MANAGEMENT}

Revenue management is a sophisticated approach by which managers may optimize both revenues and profits by employing effective capacity, pricing, and inventory controls, various distribution channels, and other tactics (Westermann, 2015; Zatta \& Kolisch, 2014). Airline managers began utilizing revenue management strategies in the early 1980s to compete with new low-cost airline entrants (Vinod, 2015). Revenue management techniques are mostly applicable to businesses characterized by fixed and perishable inventory, fluctuating demand, low sales costs with high production costs, the existence of market segmentation, and ability to sell inventory in advance (Kimes \& Wirtz, 2013). An important tenet of revenue is price differentiation, in which business managers offer different products or services at different prices across the different market (Cetin et al., 2016; Raza, 2015), driven by customer needs and therefore, demand for selected products or service attributes.

In the airline industry, business travelers make reservations closer to their travel date and have a higher willingness to pay while, leisure travelers book well in advance of their travel dates and have a lower willingness to pay (Lieberman, 2016; Vinod, 2015). With multiple customer segments characterized by different preferences, airlines forecast expected demand and reserve designated inventory (seats) to specific customer segments while limiting inventory choices to others. Through this dynamic inventory allocation technique, airline managers implemented differential pricing to extract maximum value out of a specific customer segment, thus enhancing revenues (Lieberman, 2016; Noone, 2016; Vinod, 2015). The success of revenue management for the airline industry led to the wider use in other hospitality industries.

The hotel industry emulated the airline industry structuring a fully synergistic strategy to optimize capacity (room rental) and revenue (Buckhiester, 2011). Initially, hotels leaders based their revenue management approach primarily on inventory allocation over multiple distribution channels with rates set based on demand and market conditions (Kimes, 2016). Researchers have discovered a shifting trend in the hotel industry with pricing decisions integrating all revenue generation options such as food and beverage, parking, and function room rentals as well as product and service attributes (Abrate \& Viglia, 2016; Zheng \& Forgacs, 2016). Gultek and Heroux (2019) posited that hotel managers should carefully consider alternative revenue generation options when setting room prices and allocating inventory because alternative revenue streams may contribute more to the bottom line than higher capacity at discount prices. 
Other service industries have fluctuating customer demands across time or market segments that could influence pricing approaches. Researchers have pointed out the benefits of applying revenue management techniques for processing enterprises (Zatta \& Kolisch, 2014), restaurants (Kimes \& Wirtz, 2013), golf courses (Enz \& Canina, 2016), self-storage units rental (Lieberman, 2016), and ski resorts (Malasevska \& Haugom, 2018). The managers of golf courses and ski resorts tend to rely on a traditional pricing approach based on demand variations such as weekdays versus weekends (Enz \& Canina, 2016; Malasevska \& Haugom, 2018).

To better exploit customers' willingness to pay to maximize profits, operators could shift customers into lower demand time periods at reduced prices while maintaining the full price at high demand time periods (Enz \& Canina, 2016). Lieberman (2016) found that self-storage operators exploited customer/product segmentation through automatic repricing of available units based on the relative desirability of the units. Kimes and Wirtz (2013) highlighted that the application of revenue management principle of capacity control to assign finite resources (tables) to a customer group could improve a restaurant's financial performance.

\section{Revenue Management in the Wine Sector}

The wine sector shares similar characteristics to airlines, hotels, and other service industries making winery enterprises suitable to apply revenue management strategies. The common characteristics include fixed capacity, perishable inventory, large fixed costs, uncertain variable demand, and segmented customer groups (Kimes \& Wirtz, 2013). Apart from these characteristics, winery operations have a distinctive feature that effect revenue management decisions. Federal and state-level regulations imposed on the production, sale, and distribution of wine products to consumers may determine the failure or success of revenue management strategies.

In the small-farm winery sector where multiple wine producers compete to attract winery visitors, wine products price points are a key component to build competitive strategies such as brand development and customer base growth (Maumbe \& Brown, 2013). Researchers discovered that knowledgeable wine enthusiasts are willing to pay more than uninformed customers. However, astute wine enthusiasts may not be as brand loyal (Pomarici, Lerro, Chrysochou, Vecchio, \& Krystallis, 2017). Casual wine consumers may exhibit long-term loyalty and purchase more, though they are often motivated by winery promotional and discount incentives (Kim \& Bonn, 2016; Olsen et al., 2015; Pomarici et al., 2017). Additionally, McCole et al. (2018) noted that wine tourists visited wineries in the Great Lakes region for recreational experience rather than wine purchases; however, the wine tourists spent a significant amount of money during their visits to the tasting room. Small-farm winery owners' use of pricing policy modifications to target different customer segments and exploit customers' willingness to pay increases the opportunity to improve their financial performance.

For small-farm winery owners, determining requisite levels of inventory available for specific customer segments is challenging. A decision to allocate inventory to fulfill distributors demand and other distribution channels could deplete the inventory supply available for higher margin sales channels, particularly tasting room sales to winery visitors (Velikova, Canziani, \& Williams, 2019). Newton, Gilinsky, and Jordan (2015) hypothesized that wineries with more than 50\% of their distribution through direct-to-consumer channels would outperform other wineries.

The direct-to-consumer sales are more profitable and becoming the predominant approach small-farm winery owners utilize to market and sell wine products. Researchers concluded that direct-to-consumer sales represented $60 \%$ of overall winery sales for U.S. wineries (McMillan, 2017; Tuck et al., 2016). Further, the surge of wineries in the U.S. has increased dramatically while the number of distributors decreased by nearly $90 \%$ limiting the ability of owners of small-farm wineries to obtain wholesale representation (Santiago \& Sykuta, 2016). Because of the economy of scale of small-farm wineries, operators in the Eastern Atlantic U.S. rely on direct-to-consumer sales at the winery or through low-scale distribution (Villanueva \& Moscovici, 2016).

Since wine is an alcoholic beverage, owners of small-farm wineries must abide by a unique system of federal and state laws related to the sale and distribution of wine products. Under the Federal Alcohol 
Administration Act, winery owners are required to obtain the necessary permit to engage in the business of production, sale, and distribution of alcoholic beverages including wine (U.S.C. §203, 2016). Furthermore, consumers are allowed to ship wine interstate when they purchase wine products during a winery visit and the purchases follow state-specific regulations (27 U.S.C.\$203, 2016). Small-farm winery operators are required to hold a manufacturer permit as well as an in-state transporter permit to distribute and sell wine products at the retail level directly to consumers for on or off-premise consumption. However, licensed permittees are limited in quantity and frequency of sales shipped to consumers within the state boarder in which they operate.

Wine production takes place over an extended period from initial planting to producing wine that delays the revenue stream by 3 to 5 years (West \& Taplin, 2016). Hence, small-farm winery owners could support long-term sustainability through expansion of revenue-generating on-premises activities to diversify revenue streams, supplement income, and provide complete utilization of resources. The USDA 2017 Census of Agriculture (2019) indicated that over 38,000 U.S. farms were participating in some form of nonproduct related activities generating over $\$ 940$ million in total revenue, an increase of $35 \%$ from 2012 .

While wine tourism and non-agricultural activities are achievable business ventures, winery owners must manage associated risks to gain economic benefits. According to Liang and Dunn (2016), winery operators identified access to capital and labor requirements as the major barriers to expansion in wine tourism activities. Also, researchers pointed out, owners adding new dimensions to their enterprises may need to divert limited resources away from their core wine business that could negatively impact wine operations (Liang \& Dunn, 2016; Ullah, Shivakoti, Zulfiqar, \& Kamran, 2016; Veeck, Hallett, Che, \& Veeck, 2016). Boncinelli, Bartolini, Casini, and Brunori (2016) discovered an adverse effect on farm owners' diversification decisions because of zoning regulations limiting the number of on-farm nonagricultural activities each year and capacity caps.

\section{DYNAMIC CAPABILITIES FRAMEWORK}

Owners of small-farm wineries face increasing competition, rising operation costs, and changing federal and state regulatory policies. These internal and external factors are dynamically changing, requiring winery operators to adapt their capabilities over time. Accordingly, the conceptual framework for this study was dynamic capabilities.

The dynamic capabilities framework stems from the resource-based view theory and emphasized the critical role of managerial capabilities rather than firm-specific resources to sustain competitive advantage (Teece, Pisano, \& Shuen, 1997). Teece, Pisano, and Shuen (1997) outlined the dynamic capabilities framework based on the premise that capabilities not only vary across business enterprises, but the differences are the result of management choices. The theorists defined dynamic capabilities at its disposal to address rapidly changing environments (Teece et al., 1997). The dynamic capabilities framework emphasizes the critical role of managerial capabilities rather than firm resources.

Teece and Pisano (1994) and Teece et al. (1997) conjectured that firm level differences in capabilities were framed by pre-existing asset positions, processes for reconfiguration, and paths for capability creation. Researchers indicated that possession of assets alone could not lead to sustained competitive advantage when the business environment is constantly changing (Kim, Song, \& Triche, 2015; Koryak et al., 2015; Shuen, Feiler, \& Teece, 2014). Teece et al. (1997) continued to develop dynamic capabilities to explain how and why certain business leaders proactively engage in sustainable development opportunities.

In accordance with the dynamic capabilities, Teece et al. (1997) characterized capabilities as discrete internal processes and routines within an organization rather than engagement in extemporaneous activities to address external changes. Teece (2007) furthered the research postulating the dynamic capabilities are strategic processes centered on sensing, seizing, and transforming. Ordinary capabilities are routines that firm operators employ to produce and sell existing products or services (Teece, 2018b). However, over time ordinary capabilities become easily imitable and no longer critical to competitive advantage (Teece, 2018a). Dynamic capabilities are higher level capabilities that are difficult to replicate and critical for a sustained competitive advantage. 
For companies to sustain a competitive advantage in an ever-changing business environment, they must have the ability to change or develop new capabilities. Hansen and Moller (2016) discovered business leaders created and strengthened dynamic capabilities by combining resources and reformulating processes in the implementation of lean production practices. Further, Chatterji and Patro (2014) studied how Google and Facebook reconfigured their human resource process to acquire diverse technology, talent, and intellectual property to seize the opportunity to improve existing products and create new products. Finally, Gligor, Esmark, and Holcomb (2015) discovered that supply chain agility as a dynamic capability had a significant impact on cost efficiency and customer effectiveness across various operating environments.

Family-owned enterprises possess distinct assets and resources that contribute to the long-term survival of the business. A single case study by Jones, Ghobadian, O'Regan, and Antcliff (2013) drew on the theory of dynamic capabilities to examine long the long-standing family business to establish the links between multi-generational ownership, entrepreneurial cognition, and dynamic capabilities. The researchers identified vital dynamic capabilities associated with success as (1) leveraging existing resources, (2) creating new resources, (3) accessing external resources, and (4) release of underperforming assets (Jones, Ghobadian, O'Regan, \& Antcliff, 2013). The breadth and depth of knowledge that operators of familyowned firms gain over the years is a unique resource.

Competitive advantage does not stem solely from unique resources but also business leaders' distinct capabilities in analyzing and managing such resources. Dynamic capabilities approach focuses on how the stewards of organizations continually adapt and reconfigure valuable resources to achieve and maintain competitive advantage (Alford \& Duan, 2018). Owners of small-farm wineries operate in a dynamic environment interacting with external forces such as regulatory policies, shifting consumer behaviors, and sources of competition. These external factors necessitate owners of small-farm wineries to recognize opportunities, develop revenue management strategies, and deploy and reconfigure resources to promote long-term survival.

\section{Dynamic Capabilities and the Wine Sector}

Prior research on the wine sector applied dynamic capabilities as the conceptual framework lens to examine elements in strategic decision-making. Calderón, Fayos, and Frasquet (2019) studied six wineries in Spain and found varying levels of dynamic capabilities related to multi-channel distribution. Two wineries displayed exploitation and exploration capabilities to achieve a high level of multi-channel integration. The wineries used available information for different sources to advance distribution channels into new markets while continuing to maintain relationships with existing distribution channels and markets (Calderón, Fayos, \& Frasquet, 2019). Conversely, Calderón et al. (2019) noticed that the wineries with lower levels of multi-channel distribution relied on exploration capabilities constantly researching for information but lacked exploitation capabilities to move beyond the traditional distribution channel.

Another study based on data from winery owners and managers in a multi-country study identified the link of dynamic capabilities of the organizational process (Teece, 2007), sensing, seizing, and reconfiguring to innovation strategy decision-making. Duarte Alonso, Kok, and O'Brien (2018) revealed several aspects to key innovation development to obtain competitive advantage that included creating demand through niche production and experiences, acquiring new equipment and technologies, and increasing social media and agritourism activities. Finally, dynamic capabilities increased an entity's ability to innovate and influence innovation success (Duarte Alonso, Kok, \& O’Brien, 2018).

In a third study Woodfield, Shepherd, and Woods (2016) investigated three family winegrowing businesses to understand the impact of key dynamic capabilities on business succession. Woodfield et al., (2016) noted that individuals growing up and working at family businesses accumulated strong tacit knowledge and business acumen not easily replicated by non-family members. Similarly, Chirico and Nordqvist (2010) research found dynamic capabilities were evident. Dynamic capabilities generated by the accumulation of knowledge, expertise, skills, and strategically important assets facilitated innovation and continuous improvement. The development of adaptive capabilities and resilience (sensing) enhanced wineries ability to reinvent or extend their range of resources (transforming) to gain competitive advantage (seizing) (Chirico \& Nordqvist, 2010). 


\section{SMALL-FARM WINERIES IN CONNECTICUT}

The winery sector is flourishing in Connecticut. Since the passage of the Farm Winery Act (Conn. Gen. Stat. §30-16, 2017 as amended) in 1978, commercial wineries in Connecticut grew from 1 licensed winery to 41 licensed wineries as of 2019 (DOAG. 2020). The industry is mostly comprised of small-farm wineries with production level an average of 5,100 gallons per winery (Lopez, Boehm, Pineda, Gunther, \& Carstensen, 2017). In 2015, Connecticut wineries generated total revenues of $\$ 85.5$ million which represented a 130\% increase from 2007 (Lopez et al., 2017). The wineries in Connecticut are predominantly small sized because of the lack of large tracts of land. Currently, the Connecticut small-farm wineries' acreage range from 8 to 400 acres (DOAG, 2020).

Small-farm winery operators in Connecticut are required to hold a manufacturer permit as well as an in-state transporter permit to distribute and sell wine products at the retail level directly to consumers for on or off-premise consumption (Conn. Gen. Stat. §30-16, 2017 as amended; Conn. Gen. Stat. §30-19(f), 2015). For Connecticut winery operations, $84 \%$ of all sales of wine products result from direct-to-consumer sales through the tasting room or low-scale distribution channels (Villanueva \& Moscovici, 2016). As noted by Byrd, Canziani, Hsieh, Debbage, and Sonmez (2016) and Sun, Gómez, Chaddad, and Ross (2014), tasting rooms are a high-margin, low-volume distribution channel and contribute to brand recognition. With the advent of $e$-commerce and Internet marketing, small-scale producers began to explore online sales to overcome geographical location obstacles.

The online platform has considerable potential for winery owners to broaden the customer base of a winery and promote reoccurring purchases after winery visits thus increasing sales. As $e$-commerce continued to grow, regulations by federal and state evolved. In Connecticut, licensed permittees cannot ship more than five gallons of wine in any 2-month period to any one consumer within the state borders (Conn. Gen. Stat. §30-19(f), 2015). Most recently, new state legislation lifted the prohibition of out-of-state wine retailers from shipping directly to Connecticut consumers (CT SB647, 2019) widen wine consumers access to wine products via e-commerce.

Another key aspect to the Connecticut wine sector is the state minimum in-state fruit content regulation. For owners of small-farm wineries to designate their wine products as CT Grown, the wine products must be produced using at least 25\% of grapes grown in the region (Conn. Gen. Stat. §30-16, 2017 as amended). To meet minimum in-state fruit requirements, owners may need to purchase grapes from external growers or reduce production level. Lee and Gartner (2015) discovered that a higher minimum in-state fruit content requirement negatively correlates with winery revenue levels.

In the last decade revenue from agritourism in the Connecticut wine sector increase 11.7\% (Lopez et al, 2017). The agritourism activities vary across the Connecticut wineries and relate to winery size, resource capacity and local ordinances, but also on owner's business model. Finally, the wineries in the U.S. Northeast suffer from seasonal fluctuations resulting in overutilization of resources and capacity in high season and underutilization of resources and capacity in the low season. Phan, Driml, and Walters (2018) found that in rural tourism destinations, business operators who took collective and collaborative approaches to attract and satisfy different types of tourist achieve sufficient levels of income even in the low season.

Based on the review of prior literature and examination of the wine sector in Connecticut, the following research questions are developed:

$\boldsymbol{R Q 1 .}$ What are the most significant revenue management strategic decisions among Connecticut small farm wineries?

RQ2. How are owners' dynamic capabilities contributing to the success of implemented revenue management strategies?

RQ3: What are the challenges and barriers affecting revenue management decisions by small-farm winery owners?

Journal of Applied Business and Economics Vol. 23(3) 2021165 


\section{METHODOLOGY}

\section{Research Design and Study Sample}

The qualitative approach was the methodology for this study and a multiple case study research was conducted to explore the practical application of revenue management strategies in individual enterprises. The rationale to focus the study on winery operations in one state was because of the varying state-level regulatory policies with regard to the production, sale, and distribution of wine products. The difference in state regulatory policies influence the revenue management approaches taken by owners. Through semistructured interviews with three winery owners in Connecticut purposively selected to ensure that each owner possess the knowledge and expertise, and the wineries have common attributes to reinforce sample homogeneity. The sample selection was drawn from the listing of wineries designated as CT Grown by CT Department of Agriculture (DOAG, 2019) and:

- classified as small winery based on USDA production levels (less than 50,000 cases a year);

- continuously farmed and operated profitable small-farm wineries for at least 10 years; and

- revenue generation is predominantly from winery operations.

Originally, 12 owners of winery enterprises were selected for meeting the first two inclusion conditions and sent invitations to participate via email. Subsequently, five owners accepted to participate in the study, however two were not considered because their revenue generation is predominantly focused on other agricultural operations rather than the winery. Therefore, the researcher retained the three remaining participants for this multiple case study and determined that the collection of data from the three small-farm winery owners was sufficient to achieve research objectives and support claims of data saturation. Table 1 displays the specific demographics of each participant.

TABLE 1

\section{PARTICIPANT DEMOGRAPHICS}

\begin{tabular}{cccc}
\hline & P1 & P2 & P3 \\
\hline Ownership & Family & Family & Family \\
Generation & 2 & 1 & 3 \\
Estate Grown & $93 \%$ & $55-70 \%$ & $75 \%$ \\
$\begin{array}{c}\text { Average Production } \\
\text { Level (in gallons) }\end{array}$ & 5,000 & 9,000 & 6,500 \\
\hline
\end{tabular}

Note: Demographic information retrieved from interview data, observation notes, and review of each winery website.

A secondary data collection technique was document analysis from archival data, and field notes. Sources of materials for this study included different forms of company documents such as brochures, pricing charts, tasting sheets, and events/programs calendar obtained from the owners. The researcher gathered documentary data from each winery's website through the retrieval of contextual information and other corroborative evidence. While each winery has specific characteristics that shape their business model, the results of these interviews provide practical insights on how to adapt business practices and turn constraints into opportunities aimed at product quality, exceptional service, and cost control that may sustain long-term survival.

\section{Data Collection}

Primary data was collected through semi-structured face-to-face interviews with three small-farm winery owners. Qualitative researchers noted that the point of data saturation is subjective base in part on the purpose of the study, quality of the interviews, number of interviews per participant, sampling procedures, and the researcher's experience (Marshall, Cardon, Poddar, \& Fontenot, 2013). The sample size was large enough to gain insight into the long-term survival of small-farm wineries with comparable challenges and opportunities. As suggested by Hulthén, Naslund, \& Norrman (2016), an interview protocol was followed to maintain a consistency line of inquiry that helped to mitigate any potential biases and to 
uphold the standards of a research study. A secondary data collection technique was document analysis from archival data, and field notes. Sources of materials for this study included different forms of company documents such as brochures, pricing charts, tasting sheets, and events/programs calendar obtained from the owners.

With the participants' permission, the interviews were recorded with an audio voice recorder. Each interview transcribed verbatim into Microsoft Word and imported data into NVivo software. Before commencing on the data analysis process, the researcher executed a member checking process (Lincoln \& Guba, 1985) with the participants. Each participant confirmed the accuracy of the researcher's interpretations reflected their respective views.

The researcher gathered documentary data from each winery's website (Marshall \& Rossman, 2016) through the retrieval of contextual information and other corroborative evidence. On completion of interview transcription and member checking, the researcher used the NVivo software to analyze all participants' responses and synchronize themes with the other data sources so that the findings included elements representing themes from all sources and support completeness of the research.

\section{RESEARCH RESULTS}

The findings revealed that limited implementation of a structured revenue management framework by owners. Rather the owners adjusted revenue management approaches to support building their brand and customer base. Moreover, participants exhibited that owners who developed stable networks, a quality customer base, and business model innovation enhanced long-term survival of their enterprise. With frequency, owners stated regulatory policies and resource constraints as well as competitors' impact influenced revenue management strategy decisions. The findings from this study reflected the presence of sensing, seizing, and resource configuration concepts from the theory of dynamic capabilities used in the conceptual framework of this study.

\section{Pricing Objectives to Pricing Strategies}

A major element of any revenue management decision is the pricing structure. For the participants in this study, the primary concern was setting a price point for wine products available for on-premises sale that was in the range with the retail market and competitors and reflected product attributes. Moreover, the owners underscored that as small wine producers with slim profit margins, it was more about educating customers on the value of their wine products and why the price points might be more or less expensive than their competitors.

Contrary to researchers (Back, et al., 2018; McCole, Holecek, Miller-Eustice, \& Lee, 2018), small-farm winery owners in this study seldom changed prices based on customer purchase behavior and willingness to pay. The study participants mentioned that in addition to grape varietals, cost changes in other production materials (i.e. bottle, cork capsule, labels) affected the change in pricing. One participant noted that when they raise prices sales stagnant for a time until the consumers absorb the new pricing. Finally, to increase transaction size the three study participants used case discounts on purchases only through the tasting room. Because the winery owners in this study derived majority of their revenue by direct-to-consumer sales through the tasting room, they agreed that it was important that pricing strategies target tasting room visitors.

Participants also noted that competing against other countries in the market is getter tougher. Several countries including Argentina and Chile have steadily gained market share in the U.S. with very low-price points on their products (Govindasamy, Arumugam, Zhuang, Kelley, \& Vellangany, 2018). Wholesalers increase the price of wine products typically in the $30 \%$ range over their acquisition cost when selling to retail outlets. The retailers will also add a markup to the price levels necessary to make a profit. One owner stated: 
To balance consumers' expectations when they come to the tasting room but still keeping competitive against other products in the market" small-farm winery owners need to keep the markup layers in mind when establishing the price of wine products for sale on premises.

Participants in this study also suggested that wine quality was an essential attribute in setting the price of their wine products. The findings indicated all participants had higher-priced premium products with a good margin in the mix of wine products available for sale. Upon review of each winery wine list, it was noted reserve and specialty wines were priced $25 \%$ to $60 \%$ higher. Also, all winery owners emphasized the importance of being designated CT Grown, producing wines blended from grapes grown in Connecticut. The findings showed that all small-farm winery operations exceeded the imposed $25 \%$ in-state fruit requirement (Conn. Gen. Stat. §30-16, 2017 as amended). All three study participants expressed the impetus to have the CT Grown designation was to control the types of grapes grown and how they are grown to ensure product quality and integrity.

All study participants offered ancillary services and products as alternative revenue sources while promoting their brands and wine products. The three wineries had available a range of wine-related accessories such as wine glasses, wine bottle holders, or wine décor products and perishable items including cheese and fruit plates. Furthermore, two of the three owners offered for rent tasting room space or a tent in the vineyard for private parties. As supported by the research (Liang \& Dunn, 2016; Ullah et al., 2016: Veeck et al., 2016), the study participants indicated that by diverting resources away from their core business to support the offering of ancillary products and services, negatively impact their agricultural operations.

\section{Capacity Utility and Distribution Channels}

Researchers noted that winery owners operated tasting rooms to introduce and market their wine products to consumers (Sun, Gómez, Chaddad, \& Ross, 2014; Villanueva \& Moscovici, 2016). Some participants noted that meeting the demands of their wholesale network was critical. One winery owner used the wholesalers, deriving $50 \%$ of its sales revenue from this distribution channel. The winery owner explained "because our winery is located off the beaten path and being a small winery physically, we always had a wholesale network". This small-farm winery owner noted that they fulfilled wholesale orders first then remaining inventory was available through the tasting room. While this is not a particularly effective inventory management system, the owners articulated that it was necessary to maintain a wholesale network that took years to cultivate.

All the study participants offered wine tastings, wine by the glass, and bottles of wine through their tasting rooms. The price of the wine tastings ranged from $\$ 10$ to $\$ 12$ per tasting while a glass of wine was between $\$ 8$ and $\$ 12$ depending on the varietal. Study participants acknowledged that they participated in different outside events to generate income and market their wines. However, state regulations limit participation to seven off-site farm winery sales and tastings with special permitting per year (Conn. Gen. Stat. $\S 30-16,2017$ as amended). The study participants acknowledged these activities contributed to their revenue stream, but it was repeat customers and subsequent sales of full bottles that supported long-term survival.

According to the literature, small-farm winery owners rely mostly on direct-to-consumer sales such as tasting rooms, wine clubs, Internet sales, and local distribution where profit margins are higher (Duarte Alonso et al., 2015; Sun et al., 2014). Findings from the interviews indicated that all participants limited their direct-to-consumers sales approaches to tasting rooms and local distribution. Two participants of this study cited the lack of capital resources and restrictive zoning ordinances as limitations to their ability to expand existing tasting rooms or expand ancillary services offerings. Moreover, once the tasting room is at capacity, winery owners need to ensure wine products are readily available for sale or consumption as well.

All three winery owners cited costs and resources prohibitive issues including shipping prices and employees' time in addition to high attrition rate as deterrents to offering a wine club. One owner added, "There are a lot of special pricing and incentives, and it takes a long time to make that money back". Internet 
sales have emerged as an essential method of direct-to-consumer sales. Consistent with the findings of Gilinsky, Newton, and Vega (2016), two of the three study participants indicated that varying state shipping laws and distributor control became an obstacle for Internet sales therefore not a financially feasible route for direct-to-consumer sales. Another winery owner noted that some states allow direct shipment of wine to consumers from in-state wineries but restrict direct shipment from out-of-state wineries. To overcome the costs and resources associated with compliance with state shipping laws, filling Internet sales orders, and shipping the wine products one study participant explained the sales volume has to be higher. However, the winery owners were reluctant to allocate inventory across the different distribution channel before knowing customer demand.

The study participants recognized that customers' attitudes and behaviors toward wines have shifted. Customers have become more knowledgeable and could differentiate among the grape varietals in making purchase decisions. Pomarici, Lerro, Chrysochou, Vecchio, and Krystallis (2017) noted that knowledgeable wine enthusiasts were willing to pay more than uninformed customers. All participants highlighted efforts to attract these knowledgeable customers through offering quality products and services, thus building their customer base. The participants of this study admitted that they did not have a formalized approach to managing inventory capacities instead exploited the different distribution channel when opportunities arose to increase brand awareness.

\section{Dynamic Capabilities Contribution}

All three participants of this study are family-owned and operated enterprises. Evidence indicated that the breadth and depth of knowledge that operators of family-owned firms gain over the years is a unique resource that determines an enterprise's competitive advantage within the dynamic capabilities framework (Jones et al., 2013; Teece et al., 1997). All participants indicated that providing a positive wine visitor experience was an important fact to both building their brand and sustaining long-term survival. Also, participants acknowledged that the owners' presence in the tasting room augmented the customer experience. One participant expressed the reason for their success is the family-oriented environment they created instead of just another place to come and drink. The results of this study corroborated the importance of leveraging knowledge and experience to promote exceptional wine experience as a way to build a relationship with the customer, thereby support long-term survival.

All participants of this study often mentioned location, atmosphere, and family-owned winery as contributors to their success. The study participants recognized the importance of the geographical location to building its brand and promoting long-term survival. Further, the winery owners acknowledged the benefits to providing an enjoyable wine experience and of being situated near towns that support other desirable amenities. Accordingly, this view supports research findings of McCole et al., (2018) which indicated that wine tourists who visited wineries regions for recreational experiences rather than wine purchases spent a significant amount of money during their visits to the tasting room.

Though the three small-farm winery owners in this study focused mainly on selling a quality product to promote long-term survival, the owners had different approaches to increase revenues. One winery owner developed new products to meet customers changing preferences. Specifically, the owner began producing sulfite-free wines in response to government warning on sulfites and fruit wines in response to consumers' interest in healthy food and beverages containing anti-oxidants. Another participant introduced a Portuguese-style wine as an homage to the owner's heritage. Finally, a third participant collaborated with a local distillery to produce a dark rum infused wine which was sold at a premium price. These findings supported the existing body of knowledge that managers must reconfigure resources and capabilities to align with the changing environment to attain innovative performance (Nieves \& Haller, 2014; Ou, Hsu, \& $\mathrm{Ou}, 2015)$.

All participants mentioned that labor, operating costs, and cash flow were typical constraints they must overcome to optimize profits and promote long-term survival. This finding is consistent with literature from Liang and Dunn (2016) that suggested farm operators need to reconstruct or transform available resources to minimize the impact of these certain constraints to sustain long-term survival. As a business with a 
seasonal cycle, the winery owners recognized the need to be resilient and strategic to manage their resources effectively.

Through the examination of each winery website, it was noted that all winery operations in this study remained open all year round despite the seasonality of the business. All study participants reduced hours of operation during the off-season, typically January through April, to contain costs. Furthermore, some

participants reported dynamic strategies to combat the adverse consequence of the seasonality issue similar to the findings from Pham et al. (2018). One winery owner offered discount coupons on purchases between January and April to generate some revenue and cash flow in the off-season. Also, all participants participated in the 2019 CT Winter Wine Trail that the Connecticut Farm Wine Development Council devised to promote Connecticut agricultural tourism during the winter months.

\section{Challenges and Barriers in Revenue Management Decisions}

The three participants of this study agreed that labor was the most significant resource constraint affecting revenue management strategy decisions. As Golicic, Flint, and Signori (2016) noted from their study findings wine businesses have a high level of fixed costs so controlling variable costs such as labor is crucial to an entity's long-term survival. To properly operate a small-farm winery, the owners stated that they need employees in the tasting room to serve customers, employees in the vineyard taking care of the vines as well as employees in the production room. Because the growing vines and producing wines is a labor-intensive process, the study participants limited the non-agricultural activities to their enterprises to maintain the proper level of resources directed toward their core agricultural business. Furthermore, one winery owner invested in new equipment to automate grape harvest that will reduce seasonal labor needs and new processing equipment to increase efficiency and reduce waste in the production process.

The study results showed that the owners of small-farm wineries cannot adopt effective revenue management strategies without recognizing and considering significant regulatory elements. The smallfarmer winery operators must comply with all federal and state licensing and permit requirements as well as municipal zoning codes related to the production, sale, and distribution of wine products (27 U.S.C. §203, 2016; Reynolds \& Knowles, 2014; Santiago \& Sykuta, 2016). All participants acknowledged that working within the regulatory guidelines often reduced their ability to seize opportunities arising in the marketplace.

During the interview process, the winery owners discussed regulatory issues related to business operations and ancillary services. Also, the three study participants mentioned state and local zoning laws restricted the number and type of events owners might conduct on- and off-premises thus curtailing their ability to generate revenue from alternative sources. These findings conform to the view of Boncinelli et al. (2016) of the adverse effects on farm owner's diversification decisions because of zoning regulations limiting the number of on-farm non-agricultural activities each year and capacity cap. Some of the participants raised concerns of how pending new legislation, a minimum wage increase, and $\$ .25$ deposit on wine bottles, would impact their profitability. Two of the three participants indicated they were developing strategies to anticipate the best way to distribute the additional costs of compliance to customers without affecting demand.

The common consensus among all study participants was they were facing increased competition from other wineries, importers, and other beverage enterprises. Currently, there are 41 licensed wineries in CT (DOAG, 2020) and the winery owners indicated that with the emergence of new wineries in the area, some visitors did price shop. Additionally, the owners of the new wineries were investing millions of dollars into elaborate full-service facilities to attract visitors.

According to all participants in the study, the most significant competitor to small-farm wineries is the micro-breweries. Researchers reported that craft beverage breweries and distillers in the U.S. had grown dramatically in recent decades with a large concentration of breweries in the Northeast Corridor (Carr, Fontanella, \& Tribby, 2019; Nilsson, Reid, \& Lehnert, 2018). All study participants disclosed the difficulties of competing with local breweries for several reasons. First, brewery owners can release in a shorter timeframe, new products to meet consumer demand. Conversely, wine production takes place over an extended period from planting to producing wine thus delaying distribution (West \& Taplin, 2016). The 
winery owners face the challenge of anticipating 2 to 3 years ahead customers' expectations and acceptance of new products to maintain a competitive advantage.

In the literature, researchers noted that many owners of small-farm wineries typically operate in rural geographical areas and have limited resources to attract visitors (Byrd et al., 2016; Liang \& Dunn, 2016; Villanueva \& Moscovici, 2016). Conversely, many brewery districts are emerging in the center of cities and industrial neighborhoods that are easily accessible to residents and well-situated to lure new customers (Nilsson et al., 2018). To attract wine tourists and promote their products, all three winery owners stated that by participating in the Connecticut wine trail program they could work collaboratively in a competitive market to their mutual benefit.

Finally, brewers have a more favorable legal environment in which to operate. Under CGS §30-16(h) (2017 as amended), brewers who possess a manufacturer permit for beer and brewpub can sell products in their taprooms beyond the brewery capability, which include wines and ciders. Also, customers can purchase beer in grocery stores in Connecticut but not wine. Recent legislation gives craft breweries the ability to sell more beer to customers for consumption off-premises allowing these enterprises to expand their market share (CGS §12-435, as amended 2019). All participants expressed frustration at the disparity of opportunities for winery owners to bring their products to new markets and increase the visibility of their products.

\section{DISCUSSION}

Although small-farm winery operations have certain characteristics that make them a suitable candidate for traditional revenue management strategy, winery owners tend to limit the revenue principles they put into practice (Choi, Jeong, \& Mattila, 2014). In this study, all the participants initially set the price points of wines based on grape varietals, expenses associated with the aging processes, and labor, production, and distribution costs, adjusting to the relative price point that consumers were willing to pay. The present study revealed that the small-farm winery owners in this study maintained static pricing and instead focused on optimizing revenue through purposeful inventory allocation through multiple distribution channels. Several researchers deduced that pricing strategies might vary depending upon certain factors such as customer demand, product, quantity, alternative products options, seasonality, and market conditions (Abrate \& Viglia, 2016; Enz \& Canina, 2016; Malasevska \& Haugom, 2018).

The significant indicators of revenue management strategy effectiveness among the participants were the number of winery visitors and sales volume. For example, one participant tracked the number of tastings daily and compared to the daily average sales to evaluate how often a winery visit culminated into a sales transaction. Another participant utilized a POS system to track the numbers of visitors to the winery, tastings, and eventually sales per day. One winery owner described comparing current year production and sales levels to previous year's levels as a means to measure success. The participants utilized the collected data to seize opportunities and transform resources and capabilities to introduce new products and alternative revenue streams in response to changing customer behavior.

The findings indicated that the winery owners had a revenue management strategy focused on building a relationship with customers and viewing customers as strategic assets that determine a firm's competitive advantage within the dynamic capabilities framework (Teece et al., 1997). The three participants of this study maintained that leveraging product quality, geographical location, and owners' presence in the tasting room increased customer engagement and encouraged wine purchases. This finding supports the assertion of Duarte Alonso et al. (2018) that winery owners' abilities to create brand awareness and pleasurable tasting room experience was likely to build long-term customer loyalty and generate an increase in offpremise retail sales. Each of the study participants serve similar but not identical wine products, have a unique winery story, and use distinct approaches to serve their customers. However, all participants experienced similar constraints and were impacted by the same type of competitors.

Small-farm winery owners face many constraints that influence the implementation of revenue management strategies. Velikova, Canziani, and Williams (2019) discovered price points constraints, capacity limits, and time and people resources as critical challenges for small wine producers. Results from 
this study certainly also fit in with those findings but also included the need to work within regulatory guidelines as a critical challenge. The findings are relevant to professional practice, as owners of smallfarm wineries may gain practical insights on how to adapt business practices and turn constraints into opportunities aimed at product quality, exceptional service, and costs control that may sustain long-term survival.

Competition in the alcohol beverage manufacturing industry is pervasive. Understanding how to explore and exploit unique resources and capabilities from a dynamic capabilities perspective, small-farm winery owners can successfully deploy revenue management strategies to gain competitive advantage. However, Valtakoski and Witell (2018) emphasized that not all capabilities impact firm performance equally, and competitive environments affect the importance of different capabilities. Therefore, owners of small-farm wineries should carefully consider the current business environment before investing scarce resources into alternative revenue management strategies.

One fundamental tenet of the dynamic capabilities is a business leaders' ability to sense changes in the environment and quickly reconfigure or transform organizational resources to differentiate themselves from competitors (Teece, 2007; Teece et al., 1997). Organizational resources such as technological assets, financial assets, physical assets, and managerial prowess can influence profitability and long-term survival (Teece, 2018a). Because winery owners need to operate within regulatory guidelines, all three participants stressed optimizing cost reduction, niche products and services, and capital investment to leverage environment conditions. Furthermore, since the winery owners have restricted access to distribution channels, all participants have developed specific management strategies that enabled them to compete at a pace that fits their capacity.

\section{CONCLUSION}

The purpose of this qualitative multiple case study was to explore the revenue management strategies some small-farm winery owners use to sustain long-term survival. Currently, owners of small-farm wineries in Connecticut are facing increased competition, high operating costs, and federal and state regulatory issues. Because of economic, social, and regulatory influences, implementation of successful strategic management practices such as revenue management is crucial to sustaining long-term survival. Each participant exhibited a passion and dedication to producing high-quality wines products and sharing their story and educating winery visitors about their wines. The impacts of operational constraints and competition on winery activities have increased, making it a challenge for small-farm winery owners to remain profitable and sustain long-term survival.

Because of the unique business characteristics of the wine sector, the owners did not utilize all traditional revenue management practices but instead implement those practices that best aligned with their existing business models. The findings of this study did reveal that successful small-farm winery owners knew how to adapt operational methods and processes by leveraging their limited resources to create value for their customers. Furthermore, all the winery owners in this study emphasized the importance of leveraging knowledge and experience to promote exceptional wine experience to build a relationship with the customer, thereby support long-term survival.

Small-farm winery owners should bear in mind that revenue management is not a standalone operational strategy but rather a dynamic tool that owners can utilize in combination with other internal processes to meet customers' needs, overcome operating and regulatory constraints, and mitigate competitors' impact. For example, owners of small-farm wineries could utilize better available technology to analyze customers' purchases by distribution channels to gain insight on its inventory control allocation effectiveness. By understanding purchasing patterns of wine consumers, winery operators may develop more targeted pricing strategies as well as improve ancillary services and events to promote frequency of purchases and optimize revenue stream (Abrate, Nicolau, \& Viglia, 2019; Kumar, Bezawada, \& Trivedi, 2018).

Key management strategies are necessary to influence profits and improve agricultural business performance. Researchers have found that prioritizing management strategies toward controlling operating 
costs, setting optimal selling prices and production levels, allocating resources effectively, and utilizing multiple marketing channels improved agricultural business performance (Bauman, McFadden, \& Jablonski, 2018; Lai, Widmar, Gunderson, Widmar, \& Ortega, 2018). Results from this research were consistent with many aspects of previous researchers' findings and might provide a basis from developing key management strategies for implementing revenue management initiatives, overcoming constraints challenges, and mitigating competitors' impact.

Although this study contributes to the existing literature related to the implementation of revenue management strategies in non-traditional industries, it does have potential limitations. The qualitative multiple case research design adopted may be considered a limitation because of lack of representativeness. The participants in this study were three owners managing small-farm wineries located in Connecticut that may not have been an exhaustive representation of every small-farm winery in the geographical area. Additionally, the scope of the study was narrowed to exploring only small-farm winery operations, therefore the findings may only be applicable to this specific agricultural segment but may not be suitable for other agricultural enterprises.

Further research could include expanding the number of participants or the geographical location to attain addition insights into how these small-farm winery owners sustained long-term survival in a regulated industry. Exploring other agricultural segments may uncover different success strategies and enhance the generalizability of the findings. Finally, researchers suggested that business owners must develop and integrate appropriate business strategies to sustain long-term growth (Adams, Kauffman, Khoja, \& Coy, 2016). As this study included only investigating the revenue management strategies some owners of smallfarm winery implemented, further exploration of the extent other business strategies employed, and the dynamic capabilities required in the process contribute to long-term survival.

\section{REFERENCES}

Abrate, G., \& Viglia, G. (2016). Strategic and tactical price decisions in hotel revenue management. Tourism Management, 55, 123-132. doi:10.1016/j.touran.2016.02.006

Abrate, G., Nicolau, J.L., \& Viglia, G. (2019). The impact of dynamic price variability on revenue maximization. Tourism Management, 74, 224-233. doi:10.1016/j.tourman.2019.03.013

Adams, J., Kauffman, R.G., Khoja, F.M., \& Coy, S. (2016). Looking at purchasing development through the lens of small business. Journal of Managerial Issues, 23, 145-170. Retrieved from https://www.jstor.org/joujrnal/jmanaissues

Alford, P., \& Duan, Y. (2018). Understanding collaborative innovation from a dynamic capabilities perspective. International Journal of Contemporary Hospitality, 30, 2396-2416. doi:10.1108/IJCHM-08-2016-0426

Back, R.M., Bufquin, D., \& Park, J.Y. (2018). Why do they come back? The effects of winery tourists' motivations and satisfaction on the number of visits and revisit intentions. International Journal of Hospitality \& Tourism Administration, 19, 1-26. doi:10.1080/15256480.2018.1511499

Bauman, A., McFadden, D.T., \& Jablonski, B.B.R. (2018). The financial performance implications of differential marketing strategies: Exploring farms that pursue local markets as a core competitive advantage. Agricultural \& Resource Economics Review, 47, 477-504. doi:10.1017/age.2017.34

Boncinelli, F., Bartolini, F., Casini, L., \& Brunori, G. (2016). On farm non-agricultural activities: Geographical determinants of diversification and intensification strategy. Letters in Spatial \& Resources Science, 10, 17-29. doi:10.1007/s12076-016-0168-4

Buckhiester, B. (2011). Revenue management as a multi-disciplinary business process: Part two. Journal of Hospitality Financial Management, 19(2), 97-113. doi:10.1080/10913211.2011.10653902

Byrd, E.T., Canziani, B., Hsieh, Y.C., Debbage, K., \& Sonmez, S. (2016). Wine tourism: Motivating visitors through core and supplementary services. Tourism Management, 52, 19-29. doi:10.1016/j.tourman.201506.009 
Calderón, H., Fayos, T., \& Frasquet, M. (2019). The transition of small Spanish wineries toward multichannel distribution. The role of ambidexterity. International Journal of Wine Business Research, 32(1), 139-158. doi:10.1108/IJWBR-12-2018-0071

Carr, J.K., Fontanella, S.A., \& Tribby, C.P. (2019). Identifying American beer geographies: A multiscale core-cluster analysis of U.S. breweries. The Professional Geographer, 71, 185-196. doi:10.1080/00330124.2018.1501706

Cetin, G., Demirciftci, T., \& Bilgihan, A. (2016). Meeting revenue management challenges: Knowledge, skills and abilities. International Journal of Hospitality Management, 57, $132-142$. doi:10.1016/j.ijhm.2016.06.008

Chatterji, A., \& Patro, A. (2014). Dynamic capabilities and managing human capital. The Academy of Management Perspectives, 28(4), 395-408. doi:10.5465/amp.2013.0111

Chirico, F., \& Nordqvist, M. (2010). Dynamic capabilities and trans-generational value creation in family firms: The role of organizational culture. International Small Business Journal, 28, 487-504. doi:10.1177/0266242610370402

Choi, C., Jeong, M., \& Mattila, A.S. (2014). Revenue management in the context of movie theaters: Is it fair? Journal of Revenue and Pricing Management, 14, 72-83. doi:10.1057/rpm.2014.30

Conn. Gen. Stat. §12-435 (2019 as amended). (n.d.). Tax on sale of alcoholic beverages. Retrieved from https://www.cga.ct.gov/current/pub/chap.220.htm\#sec_12_435

Conn. Gen. Stat. §30-16 (2017 as amended). (n.d.). Manufacturer permit. Retrieved from https://www.cga.ct.gov/2015/ACT/PA/2015PA-00024-R00SB-00386-PA.html

Conn. Gen. Stat. §30-19(f). (2015). In-state transporter permit. Retrieved from https://www.cga.ct.gov/2008/ACT/Pa/pdf/2008PA-00187-R00SB-00627-PA.pdf

Connecticut Department of Agriculture [DOAG]. (2020). Connecticut Farm Wineries and Vineyards. Retrieved March 9, 2020, from http://www.ct.gov/doag/cwp/view.asp?a=3260\&q=399108

Connecticut SB647. (2019). 2019 Regular Session (June 11, 2019). Retrieved from https://www.cga.ct.gov/2019/act/pa/pdf/2019PA-00024-R00SB-00647-PA.pdf

Duarte Alonso, A.D., Bressan, A., O’Shea, M., \& Krajsic, V. (2015). Perceived benefits and challenges to wine tourism involvement: An international perspective. International Journal of Tourism Research, 17, 66-81. doi:10.1002/jtr.1967

Duarte Alonso, A.D., Kok, S.K., \& O’Brien, S. (2018). Understanding approaches to innovation through dynamic capabilities lens: A multi-country study of the wine industry. International Journal of Innovation Management, 23(6), 1-30. doi:10.1142/S1363919619500543

Enz, C.A., \& Canina, L. (2016). Competitive pricing in the golf industry. Journal of Revenue \& Pricing Management, 16, 139-153. doi:10.1057/s41272-016-0075-8

Federal Alcohol Administration Act 27 U.S.C. $\S \S 201-212$. (2016).

Fusch, P.I., \& Ness, L.R. (2015). Are we there yet? Data saturation in qualitative research. The Qualitative Report, 20, 1408-1416. Retrieved from http://www.nova.edu

Gligor, D.M., Esmark, C.L., \& Holcomb, M.C. (2015). Performance outcomes of supply chain agility: When should you be agile? Journal of Operations Management, 33/34, 71-82. doi:10.1016/j.jom.2014.10.008

Golicic, S.L., Flint, D.J., \& Signori, P. (2016). Building business sustainability through resilience in the wine industry. International Journal of Wine Business Research, 29, 74-97. doi:10.1108/IJWBR02-2016-0005

Govindasamy, R., Arumugam, S., Zhuang, J., Kelley, K.M., \& Vellangany, I. (2018). An econometric analysis of consumer's willingness to buy locally produced wine: A study in the mid-Atlantic U.S. Economic Affairs, 63, 489-495. doi:10.30954/0424-2513.2.2018.27

Gultek, M., \& Heroux, L. (2019). Marketing strategies of alternative revenue sources for full-service hotels in the United States and Canada: A comparative revenue management approach. Journal of Tourism \& Hospitality Management, 7(2), 1-9. doi:10.15640/jthm.v7n2a1

Hansen, D., \& Moller, N. (2016). Conceptualizing dynamic capabilities in lean production: What are they and how do they develop? Engineering Management Journal, 28(4), 194-208.

174 Journal of Applied Business and Economics Vol. 23(3) 2021 
doi:101080/10429247.2016.1238727

Hulthén, H., Naslund, D., \& Norrman, A. (2016). Framework for measuring performance of the sales and operations planning process. International Journal of Physical Distribution \& Logistics Management, 46, 809-835. doi:10.1108/IJPDLM-05-2016-0139

Jones, O., Ghobadian, A., O'Regan, N., \& Antcliff, V. (2013). Dynamic capabilities in a sixth-generation family firm: Entrepreneurship and the Bibby Line. Business History, 55, 910-941. doi:10.1080/00076791.2012.744590

Kim, H., \& Bonn, M.A. (2016). Authenticity: Do tourist perceptions of winery experience affect behavioral intentions? International Journal of Contemporary Hospitality Management, 28, 839859. doi:10.1108/IJCHM-05-2014-0212

Kim, M., Song, J., \& Triche, J. (2015). Toward an integrated framework for innovation in service: A resource-based view and dynamic capabilities approach. Information Systems Frontier, 17, 533546. doi:10.1007/s10796-014-9505-6

Kimes, S.E. (2016). The evolution of hotel revenue management. Journal of Revenue \& Pricing Management, 15, 247-251. doi:10.1057/rpm.2016.27

Kimes, S.E., \& Wirtz, J. (2013). Revenue management: Advanced strategies and tools to enhance firm profitability. Foundations \& Trends in Marketing, 8, 1-68. doi:10.1561/1700000037

Koryak, O., Mole, K.F., Lockett, A., Hayton, J.C., Ucbasaran, D., \& Hodgkinson, G.P. (2015). Entrepreneurial leadership, capabilities and firm growth. International Small Business Journal, 33, 89-105. doi:10.1177/0266242614558315

Kumar, A., Bezawada, R., \& Trivedi, M. (2018). The effects of multichannel shopping on customer spending, customer visit frequency, and customer profitability. Journal of Association of Consumer Research, 3, 294-311. doi:10.1086/698876

Lai, J., Widmar, N.J.O., Gunderson, M.A., Widmar, D.A., \& Ortega, D.L. (2018). Prioritization of farm success factors by commercial farm managers. International Food \& Agribusiness Management Review, 21, 817-832. doi:10.22434/IFAMR2017.0035

Lee, W.F., \& Gartner, W.C. (2015). The effect of wine policy on the emerging cold-hardy wine industry in the northern U.S. states. Wine Economics \& Policy, 4, 35-44. doi:10.1016/j.wep.2015.04.002

Liang, K., \& Dunn, P. (2016). Understanding barriers for and information seeking strategies by agritourism entrepreneurs in New England. Journal of Business \& Entrepreneurship, 27(2), 149 167. Retrieved from https://www2.stetson.edu/asbe/jbe/

Lieberman, W. (2016). The evolution of market segmentation in revenue management and dynamic pricing. Journal of Revenue \& Pricing Management, 15(3/4), 283-292. doi:10.1057/rpm.2016.6

Lim, E. (2017). Factors associated with success and failure in Puget Sound wineries. Journal of Wine Research, 28(3), 239-254. doi:10.1080/09571264.2017.1358157

Lincoln, Y.S., \& Guba, E.G. (1985). Naturalistic inquiry. Newbury Park, CA: Sage.

Lopez, R.A., Boehm, R., Pineda, M., Gunther, P., \& Carstensen, F. (2017). Economic impacts of Connecticut's agricultural industry: Update 2015, (Zwick Center for Food and Resource Police Outreach Report No. 47). Storrs: University of Connecticut, Connecticut.

Malasevska, I., \& Haugom, E. (2018). Optimal prices for alpine ski passes. Tourism Management, 64, 291-302. doi:10.1016/j.tourman.2017.09.006

Marshall, B., Cardon, P., Poddar, A., \& Fontenot, R. (2013). Does sample size matter in qualitative research? A review of qualitative interviews in IS research. Journal of Computer Information Systems, 54(1), 11-22. doi:10.1080/08874417.2013.11645667

Marshall, C., \& Rossman, G. (2016). Designing qualitative research (6th ed.). Thousand Oaks, CA: Sage.

Maumbe, B.M., \& Brown, C. (2013). Entrepreneurial and buyer-driven local wine supply chains: Case study of Acres of Land winery in Kentucky. International Food \& Agribusiness Management Review, 16(1), 137-159. doi:10.22004/ag.econ.144677

McCole, D., Holecek, D., Miller-Eustice, C., \& Lee, J.S. (2018). Wine tourists in emerging wine regions: A study of tasting room visitors in the Great Lakes region of the U.S. Tourism Review International, 22, 153-168. doi:10.3727/154427218X15319286372306 
McMillan, R. (2017). State of wine industry. Silicon Valley Bank. Retrieved April 30, 2019, from https://www.svb.com/wine-report/

Newton, S.K., Gilinsky, A., \& Jordan, D. (2015). Differentiation strategies and winery financial performance: An empirical investigation. Wine Economics \& Policy, 4, 88-97. doi:10.1016/j.wep.2015.10.001

Nieves, J., \& Haller, S. (2014). Building dynamic capabilities through knowledge resources. Tourism Management, 40, 224-232. doi:10.1016/j.tourman.2013.06.010

Nilsson, I., Reid, N., \& Lehnert, M. (2018). Geographic patterns of craft breweries at the Intraubran Scale. The Professional Geographer, 70, 114-125. doi:10.1080/00330124.2017.1338590

Noone, B.N. (2016). Pricing for hotel revenue management: Evolution in an era of price transparency. Journal of Revenue \& Pricing Management, 15, 264-269. doi:10.1057/rpm.2015.15

Olsen, J.E., Atkin, T., Thach, L., \& Cuellar, S.S. (2015). Variety seeking by wine consumers in the southern states of the U.S. International Journal of Wine Business Research, 27, 260-288. doi:10.1108/IJWBR-08-2014-0036

Ou, Y.C., Hsu, L.C., \& Ou, S.L. (2015). Social capital and dynamic capability driving competitive advantage: The moderating role of corporate governance. International Business Research, 8(5), 1-18. doi:10.5539/ibr.v8n5p1

Pham, L.D.Q., Driml, S., \& Walters, G. (2018). Managing seasonality in rural destinations: A case study of South Gippsland - Australia. Tourism Recreation Research, 43, 445-455. doi:10.1080/02508281.2018.1476204

Pomarici, E., Lerro, M., Chrysochou, P., Vecchio, R., \& Krystallis, A. (2017). One size does (obviously not) fit all: Using product attributes for wine market segmentation. Wine Economics \& Policy, 6 , 98-106. doi:10.1016/j.wep.2017./09.001

Raza, S.A. (2015). An integrated approach to price differentiation and inventory decisions with demand leakage. International Journal of Production Economics, 164, 105-117. doi:10.1016/j.ijpe.2014.12.020

Retrieved from http://narea.org

Reynolds, D., \& Knowles, C. (2014). Do U.S. state laws affect per capita wine purchases. Journal of Foodservice Business Research, 17, 19-27. doi:10.1080/15378020.2014.886907

Santiago, M., \& Sykuta, M. (2016). Regulation and contract choice in the distribution of wine. Journal of Wine Economics, 11, 216-232. doi:10.1017/jwe.2015.34

Shuen, A., Feiler, P.F., \& Teece, D.J. (2014). Dynamic capabilities in the upstream oil and gas sector: Managing next generation competition. Energy Strategy Reviews, 3, 5-13. doi:10.1016/j.esr.2014.05.002

Sun, L., Gómez, M.I., Chaddad, F.R., \& Ross, R.B. (2014). Distribution channel choices of wineries in emerging cool climate regions. Agricultural \& Resource Economics Review, 43, 87-103.

Teece, D.J. (2007). Explicating dynamic capabilities: The nature and microfoundations of (sustainable) enterprise performance. Strategic Management Journal, 28, 1319-1350. doi:10.1002/smj.640

Teece, D.J. (2018a). Dynamic capabilities as (workable) management systems theory. Journal of Management \& Organization, 24, 359-368. doi:10.1017/jm0.2017.75

Teece, D.J. (2018b). Business models and dynamic capabilities. Long Range Planning, 51, 40-49. doi:10.1016/j.lrp.2017.06.007

Teece, D.J., \& Pisano, G.P. (1994). The dynamic capabilities of firms: An introduction. Industrial and Corporate Change, 3, 537-556. doi:/10.1093/icc/3.3.537-a

Teece, D.J., Pisano, G., \& Shuen, A. (1997). Dynamic capabilities and strategic management. Strategic Management Journal, 18, 509-533. doi:10.1002/(SICI)1097-0266(199708)

Tuck, B., Gartner, W., \& Appiah, G. (2016). Wineries of the north: 2016 status report. Retrieved from https://www.extension.umn.edu/community/economic-impact-analysis/reports/docs/2016-mnvineyard-winery-summary.pdf

U.S. Alcohol and Tobacco Tax and Trade Bureau [TTB]. (2019). Bonded wine producers count by state. Retrieved June 3, 2019, from https://www.ttb.gov/foia/frl.shtml

176 Journal of Applied Business and Economics Vol. 23(3) 2021 
U.S. Department of Agriculture National Agricultural Statistics Service [USDA, NASS]. (2019). 2017 Census of Agriculture. Retrieved from https://www.nass.usda.gov/Publications/AgCensus/2017/

U.S. Department of Agriculture National Agricultural Statistics Service [USDA, NASS]. (2017). Agricultural statistics 2017. Retrieved from https://www.nass.usda.gov/Publications/Ag_Statistics/2017/Complete\%20Ag\%20Stats\%202017. pdf

Ullah, R., Shivakoti, G.P., Zulfiqar, F., \& Kamran, M.A. (2016). Farm risks and uncertainties: Sources, impacts and management. Outlook on Agriculture, 45, 199-205. doi:10.1177/0030727016665440

Valtakoski, A., \& Witell, L. (2018). Service capabilities and servitized SME performance: Contingency on firm age. International Journal of Operations \& Production Management, 38, 1144-1164. doi:10.1108/IJOPM-06-2016-0328

Veeck, G., Hallett, L., Che, D., \& Veeck, A. (2016). The economic contributions of agricultural tourism in Michigan. Geographical Review, 106, 421-440. doi:10.111/j.1931-0846.2016.12161.x

Velikova, N., Canziani, B., \& Williams, H. (2019). Small winery-restaurant relationship building: Challenges and opportunities. International Journal of Wine Business Research, 31, 5-11. doi:10.1108/IJWBR-07-2018-0038

Villanueva, E.C., \& Moscovici, D. (2016). Sustainable wine tourism development in burgeoning regions: Lessons from New Jersey and Connecticut. International Journal of Economics \& Business Research, 12, 313-333. doi:10.1504/IJBER.2016.10002107

Vinod, B. (2015). The expanding role of revenue management in the airline industry. Journal of Revenue \& Pricing Management, 14, 391-399. doi:10.1057/rpm.2015.40

West, G.P., \& Taplin, I.M. (2016). Making wine and making successful wineries: Resource development in new ventures. International Journal of Organizational Analysis, 24, 123-144. doi:10.1108/IJOA-02-2014-0741

Westermann, D. (2015). Important aspects to allow revenue management to deliver. Journal of Revenue \& Pricing Management, 14, 123-126. doi:10.1057/rpm.2014.42

Woodfield, P.J., Shepherd, D., \& Woods, C. (2016). How can family winegrowing businesses be sustained across generations? International Journal of Wine Business Research, 29, 122-139. doi:10.1108/IJWBR-12-2015-0052

Zatta, D., \& Kolisch, R. (2014). Profit impact of revenue management in the process industry. Journal of Revenue \& Pricing Management, 13, 483-507. doi:10.1057/rpm.2014.14

Zheng, C., \& Forgacs, G. (2016). The emerging trend of hotel total revenue management. Journal of Revenue \& Pricing Management, 16, 238-245. doi:10.1057/s41272-0 